INTERNATIONAL JOURNAL OF MULTIDisciplinARY RESEARCH AND ANALYSis

ISSN(print): 2643-9840, ISSN(online): 2643-9875

Volume 04 Issue 10 October 2021

DOI: 10.47191/ijmra/v4-i10-14, Impact Factor: 6.072

Page No.- 1431-1434

\title{
Curatorial Projects in Fine Arts of Uzbekistan
}

Tolqin Akhmedov

Researcher, National Institute of Fine Arts and Design named after Kamoliddin Behzod

ABSTRACT: The article deals with curatorial projects, international biennials and the participation of local artists, their achievements and the impact of the renewal process on art in general, which entered the modern fine arts of Uzbekistan in the late twentieth and early twenty-first centuries. In this process, our artists have adapted to the growing interest in world art trends, to the new postmodern trends of Western aesthetics, to the growing process and the general environment for all.

KEYWORDS: Curator, exhibition, idea, project, biennale, festival, performance, installation, video art, space and time, Asian art.

\section{INTRODUCTION}

In the mid-1990s, new exhibition projects began to emerge. Along with personal and thematic exhibitions, it has become a tradition to hold events dedicated to various historical and events. Since the 2000s, curatorial projects by critics and art critics have grown in number and quality. One such project in Tashkent was initiated by the Swiss Bureau in cooperation with the State Embassy and the Academy of Arts of Uzbekistan. The "Seismograph" Exhibition began in the 1980s and early 1990s. They exhibited works by painters who presented the "Union of 23" or works that were close to its ideas and principles.

The peculiarity of this project is that in its concept and unusual exposition solutions, the exhibition space is designed as special curators in the area covered with huge black fabrics - Swiss art critic F. Fray, art critic L. Kodzaeva and artist B. Ismailovs appointed. The successful naming gives the curators an idea of its content. It was a great novelty to reflect the reflexes of the creative palette of Uzbek artists of the perestroika and the first years of independence.

\section{THE MAIN FINDINGS AND RESULTS}

Since the mid-1990s, N. Ahmedova has played a significant role in the development of the curatorial movement in Uzbekistan. He defended his doctoral dissertation on Central Asian art and organized the exhibition on this basis. Thanks to his initiative, the "Asia-Art" Biennale was organized in Tashkent in 1996. N.Akhmedova's main aspiration was to bring national art into the international context. He drew our attention to the artists' focus on new forms of contemporary art. By this time, these new forms of art had already begun to enter neighboring Kazakhstan and Kyrgyzstan. In Uzbekistan, it began with the "Asia-Art" regional exhibition. In 1995, at the second exhibition, representatives of Kazakhstan (Kokserek Gallery, etc.) brought installations, objects and performances. It sounded very new to us, because it would be the first time in Central Asia. The curator of the first Biennale was N. Ahmedova. Her efforts and aspirations were aimed at bringing national art closer to world trends, and in the early 2000s it bore its first fruit. In the early 2000s, installations, video art, and performances began to take on new forms of plastic expression in Tashkent, new to many painters.

At the large curatorial exhibition "Constellation", dedicated to contemporary art, N. Ahmedova aimed to bring our artists into contact with contemporary art. The exhibition, which took place in the workshops of one of the abandoned enterprises in Tashkent, left a strong impression on the audience and experts.

Unusual installations, organically inscribed in the rooms of the half-ruined workshops, art-facts of the rats on display, installations in the form of a Mebius ribbon clinging to the walls, a huge burnt stick, all a combination of postmodern appearance, expressiveness and surprise. Later, N.Akhmedova created a number of curatorial projects, which were distinguished by their non-standard conceptual statements and tasks.

One of the main tasks of the curatorial activity and content was to apply the ideas and forms of topical art in the defined projects to the national artistic practice. In this process, our artists have adapted to the growing interest in world art trends, to the new postmodern trends of Western aesthetics, to the growing process and the general environment for all. 


\section{Curatorial Projects in Fine Arts of Uzbekistan}

As early as the mid-2000s, this process led to the study of the environment of three-dimensional installations instead of two-dimensional painted fabric space. The artists' interest in contemporary art became so noticeable and active that the movement of the national painting crisis and its sense of receding into the background emerged. This factor led to the creation of a series of curatorial projects by art critic A. Khakimov. Its purpose is to rehabilitate bench painting space and twodimensional space aesthetics, and to enable them to blend traditional visual and new contemporary art spaces. From 2007 to 2012, 7 exhibition projects of fine arts were prepared and exhibited in the halls of the Gallery of Fine Arts. "Four Dimensions of the Tetragon-Reality" (2007), "The Theft of the Cocoon" (2007), "Lunolica" (2008), "Turkestansky Remake" (2009), "The Aesthetics of Hedonism: Food, Body, Spirit" (2011), "Geneology , The Tree of Memory"(2012) and" Aristotle the Cow "(2016).

Despite the diversity of conceptual ideas and tasks, all projects had a common content. They demonstrated visual acuity. In addition to the bench paintings, works created in topical art formats - installations, video art, or performance works - were also presented, but did not result in a situation such as eclecticism or incompatibility of expositions [1.284-286].

In 2013, the 1st issue of the magazine "Art" published an article by Doctor of Arts Kamola Akilova entitled "German fine and photographic art in Uzbekistan". The author of the article notes that Germany has been considered a major cultural center of Europe for many centuries, and its influence on the development of art in different countries can be felt, He admits that the treasury of German classical fine arts has been enriched with works by artists such as Albert Durer, Matis Grunevald, Caspar David Friedrich, Johann Friedrich Overbeck, Peter von Carnelius. German contemporary art is a clear historical reality, a specific social and political context, an artistic environment, a mentality, a product of tradition and at the same time a rejection of it".

Joint exhibitions of the Goethe Institute (Tashkent and Foreign Relations Institutions (IFA)), which have been held regularly in recent years, have played an important role in introducing the Uzbek audience to the unique contemporary art of Germany [3.22-24].

They became a spiritual force that allowed them to get acquainted with German art and culture, to understand the heart of the German people. Because these exhibitions presented not only the megastars of the German people, but also the European avant-garde and postmodern in general. Every artist has his own life and social destiny.

The exhibition of the famous German graphic artist Max Ernst (Uz TSG, 2006), which took a leading place in the art of the twentieth century, was held for the first time. William Rubin, an American curator from the New York Museum of Modern Art, praised Max Ernst's work. Due to the immense diversity of his styles and techniques, Picasso remained in the same position for surrealism and Dadaism as he was for twentieth-century art in general [3.20-22]. Max Ernst's world is a world of imaginary, imaginary, extremely restless, surrealistic, bird-headed people, unrealistic images of fantastic creatures, metamorphoses, distorted shapes, proportions.

His world and images have a deep significance, expressing not only the artistic, but also the civic, humanistic views of the artist, who opposed the instability, ugliness of his time, the brutality of the war years. Max Ernst's works are a mix and collage, photo report, auxiliary materials in graphic techniques that reflect the individual feelings and conceptual thinking of the artist."

October 4-8, 2018 in Uzbekistan will be held "Art and Technology. The VII Tashkent International Biennale of Contemporary Art "Confirmation and Denial" was held. The exhibition in Tashkent and Bukhara featured paintings, graphics, sculpture, photography, video art, installations and performances by more than a hundred artists from Russia, the United States, Europe, Latin America, South, East and Central Asia. Academician Akbar Hakimov, a member of the jury for the VII Buennel, wrote an article on the problems of this international forum [2.4-10].

"If you look closely, this international art project in Tashkent cannot be considered a biennial exhibition. Because more than two years have passed since the biennial was held in our capital in recent years. However, this delay also had a positive effect: the organizers were able to prepare more carefully for the reception of conference participants. First of all, the number of exhibition grounds has increased. In Tashkent alone, the Central Exhibition Hall of the Academy of Arts of Uzbekistan, the Tashkent House of Photography, the Ikuo Hiroyama Cultural Caravanserai, the Fine Arts Gallery of Uzbekistan and many other fine arts were handed over to the biennial participants. It emphasizes the great role of the Gallery of Fine Arts of Uzbekistan in bringing modern art of Uzbekistan to the international level, its demonstration and promotion [2.4-10].

\section{OUR ART AT THE BIENNALE}

The main purpose of the Biennale was to establish a process of creative dialogue and exchange of experiences through dialogue and exchange of experiences, on this basis to monitor the current state of our national art in line with world art trends. Active search of Uzbek artists in the field of contemporary art since the 2000s. Their creation of installations and video-art in the form of materialized constructions, unfortunately, came to a halt in later years. Video art and classical installation, which are considered to be advanced and up-to-date as a result of the introduction of new technical means of expression in the field of 


\section{Curatorial Projects in Fine Arts of Uzbekistan}

modern art, independent use of digital and virtual format $3 \mathrm{~d}$ technologies in developed countries of Europe, Russia, USA, Japan, South Korea, China, Southeast Asia such art forms began to appear as creative archaic types that required extra cost and labor. The new virtual reality is changing our previous perceptions in this regard. However, in the practice of national art, old forms of expression are still accepted as artifacts that define new research.

At the Biennale, a contemporary Uzbek painter was shown at the Youth Creativity Palace on the example of paintings and compositions that respond weakly to the idea that stable trends in painting have prevailed since 2010. A.Isaev, G.Kadirov, M.Esonov, F.Ahmadaliev, I.Sendler and other well-known artists took part in the exhibition at this biennale. Honestly, some of them even referred to old paintings that didn't quite fit the spirit of this biennale. New non-traditional plastics appeared in the works of A. Isaev "Heart intensity", T. Fadeeva "Magicians. Last gifts" and M. Esonov "Sogdiana".

M.Vardanyan and D.Rahmonbekova presented their compositions on a large wall. While D.Rahmonbekova interpreted the motifs of Uzbek dance, M.Vardanyan placed thin vertical lines on the wall reminiscent of abrband fabrics. E. Beknazarov presented a brightly colored diptych "Pregnancy" in the ethno-design textile style, the name of which has two meanings. Although his appearance is new, his style is traditional. The young artist U.Rajabov's painting "The Lost Story" makes a similar impression.

Artists hide today into the past As much as the art session is technologically interesting, it continues to be an indifferent direction to the acute social problems of our past culture and modern life. However, at the same time, the conflict between the cultural values of the East and the West, in particular, the issue of terrorism perpetrated by religious extremist groups, is gaining an inherent existential urgency. The religion of Islam is now gaining a new spectrum of influence as the world community enters modern life. The events that shook the whole world at the beginning of the XXI century - the explosion in New York in September 2001, the formation of the Islamic State, many countries around the world. In particular, the terrorist attacks in France, Britain, Germany, the war in the Middle East and the migration of Muslims to Europe have created a new political map of the world. In this context, a community of politicians and experts accustomed to pragmatism has to look for a positive image of Islam in the cultural sphere.

Interestingly, we did not see representatives of traditional painting among the winners. Jabborov's postmodernist paintings in his own style are, of course, an exception. Probably, the reason for this was the involvement of foreign experts working in the field of integration of modern technologies and art [2.4-10].

Frankly speaking, three or four years ago, Uzbek artists were not yet ready to create virtual artifacts based on advanced technology. But times are changing. Now Uzbekistan, like all other industries, aims to master the new technological experience of the world, and in this process requires a careful approach to unusual technological means as a delicate "matter". This is the dangerous side of resorting to new digital technologies. It is the manual labor, the skill of the individual aspects that reveal the author's personality, that leads to the spontaneous disappearance of the original handwriting.

The process of technocratic copying of virtual art facts intensifies the devaluation of the concept of "I" in the creator. Nevertheless, today's era requires the creator to resort to new approaches. The general desire to learn from the experience of the global technology industry puts before our specialists the task of transferring the curriculum of art universities (while maintaining the base of the academic school) to previously unknown modern models, studying the world experience in the use of advanced art technologies.

\section{CONCLUSION}

According to the organizers, the VII Tashkent Biennale was held in order to "exchange creative experience in the international arena, create conditions for improving the professional skills of artists in the field of contemporary art, establish long-term cultural ties between the countries". Has the above tasks been fully achieved in the process of organizing the Biennale? Of course, these goals, which are large-scale and promising, cannot be achieved at the same time. Nevertheless, it is clear that the Biennale of Contemporary Art will yield positive results and have a positive impact as a result of the efforts of the organizers to achieve the goals set.

\section{REFERENCES}

1) Akbar Khakimov. History of art of Uzbekistan. -2018. Tashkent: P. 284-286.

2) Akbar Hakimov. Clear sky over Palmyra. - // Art. 2018. Issue 4. Pages 4-10.

3) Kamola Oqilova. German fine and photographic art in Uzbekistan. -Art. Issue 2013.1.P. 20-24; 22-24;22.

4) Ibragim Abdurahmonov(2018). Reflection of Written Dastans in Maveraunnahr Miniature (XIV-XVII Centuries) //International journal of research. With Impact Factor 5.60. Dectmber. 2018. P.425-432.

5) Ibrahim Abdurahmonov. Painter of Folk Poems. -//Art, 2018. №2. P.31-35. 


\section{Curatorial Projects in Fine Arts of Uzbekistan}

6) Ibrohim Rahimovich Abdurahmonov(2020). Concept of mythology represented in fine arts of Uzbekistan.- //Asian Journal of Multidimensional Research. Impact Factor: SJif 2020=6.882. Vol.9, Issue 10, October 2020. P.143-147.

7) Ibrokhim Abdurakhmanov, (2019) "Specific peculiarities and value of legendary themes in the practical apply art," Culture and Arts of Central Asia: Vol. 10: No. 1, Article 12. Available at: https://uzjournals.edu.uz/cacenas/vol10/iss1/12.

8) Abdurahmanov I. The evolution of mythological themes in the art of Uzbekistan. Academic research in educational sciences. 2021/3.2 (3). P.500-508.

9) Ibrahim Abdurahmonov. Interpretation of mythological themes in Sughd art of V-VIII centuries .- // Bulletin of the National Institute of Art and Design named after Kamoliddin Behzod. Tashkent; 2021. №2. P.23-30.

10) Ibrohim Rahimovich Abdurahmonov (2021). He Interpretation Of Images On Dualism, Totemism, Animism And Fetishism. The American Journal of Social Science and Education Innovations (ISSN-2689-100X). Impact Factor. 2021.5.857.P.75-81. 